\title{
The Effect of Dissolved Humic Acids on Aluminosilicate Formation and Associated Carbon Sequestration
}

\author{
Ashaki A. Rouff, ${ }^{1}$ Brian L. Phillips, ${ }^{2}$ Stacey G. Cochiara, ${ }^{2}$ and Kathryn L. Nagy ${ }^{3}$ \\ ${ }^{1}$ School of Earth and Environmental Sciences, Queens College CUNY, Flushing, NY 11367, USA \\ ${ }^{2}$ Department of Geosciences, Stony Brook University, Stony Brook, NY 11794, USA \\ ${ }^{3}$ Department of Earth and Environmental Sciences, University of Illinois at Chicago, Chicago, IL 60607, USA
}

Correspondence should be addressed to Ashaki A. Rouff, ashaki.rouff@qc.cuny.edu

Received 20 September 2011; Revised 19 November 2011; Accepted 19 November 2011

Academic Editor: Teodoro Miano

Copyright (C) 2012 Ashaki A. Rouff et al. This is an open access article distributed under the Creative Commons Attribution License, which permits unrestricted use, distribution, and reproduction in any medium, provided the original work is properly cited.

\begin{abstract}
Allophane and imogolite neogenesis in soils may occur in the presence of organic matter. To understand this process under conditions relevant to soils, the influence of dissolved organic carbon (DOC) as humic acid (HA), on aluminosilicate formation was studied at $25^{\circ} \mathrm{C}, \mathrm{pH} 6$, and low-DOC concentrations. For solutions with initial Al/Si ratios of 1-2.1, and 0-6 mg/L DOC, precipitates recovered after $20 \mathrm{~h}$ had $\mathrm{Al} / \mathrm{Si}$ ratios of 2.2-2.7. The formation of allophane, imogolite-like material, and aluminosilicate gel was confirmed by XRD, FTIR, and NMR. The effect of DOC was to produce a small, but systematic increase in imogolite-like $\mathrm{Si}$ in the precipitate, and a decrease in the formation of aluminosilicate gel. Results suggest that the presence of DOC as HA slows the otherwise rapid polymerization of $\mathrm{Al}$ and $\mathrm{Si}$ at low temperature, and may also promote the formation of imogolite. The high $\mathrm{C}$ content of these precipitates indicates that this process may facilitate the sequestration of organic matter, slowing $\mathrm{C}$ cycling in soils.
\end{abstract}

\section{Introduction}

Complexation of Al with natural organic matter is important for the development of soils, influencing both the weathering and neogenesis of Al-bearing minerals [1] including aluminosilicate clays. The metastable clay minerals allophane and imogolite, when present, may control the solubility of both $\mathrm{Al}$ and Si relative to more stable phases such as gibbsite and kaolinite [2]. Allophane and imogolite are poorly crystalline hydroxyaluminosilicates with $\mathrm{Al} / \mathrm{Si}$ ratios ranging from $0.5-4$. They are composed of $\mathrm{Si}$ and $\mathrm{Al}$ polyhedral layers shaped into hollow tubes and spheres [3]. Imogolite, $(\mathrm{OH})_{3} \mathrm{Al}_{2} \mathrm{O}_{3} \mathrm{SiOH}$ [4], which has long-range order, is tubular in shape and has an Al/Si ratio of 2. Allophane has shortrange order and forms hollow spherules with a range of $\mathrm{Al} / \mathrm{Si}$ ratios. Al-rich allophane is also called protoimogolite or imogolite-like allophane and has an $\mathrm{Al} / \mathrm{Si}$ ratio of 2 [4]. Imogolite and allophane occur frequently as, but are not limited to, what are termed allophanic horizons in volcanic soils such as andisols and spodosols [5]. Their occurrence is contingent upon conditions such as soil $\mathrm{pH}$, the availability of sufficient $\mathrm{Si}$, and the presence of organic material, which can either inhibit the formation of [5], or conversely, stabilize these minerals [6]. The large surface area and high reactivity of these minerals promote complexation with organic matter [6], the essential soil nutrients $\mathrm{P}$ and $\mathrm{N}$, and toxic contaminants such as $\mathrm{As}, \mathrm{Cd}, \mathrm{Cu}$, and $\mathrm{Pb}[7,8]$.

Laboratory synthesis of aluminosilicate phases in the presence of organic constituents has been previously explored. Organic additives such as quercetin [9] and organometalloid reagents such as aluminum-sec-butoxide (ASB) and tetraethoxysilane (TEOS) $[10,11]$ were used to synthesize aluminosilicates including kaolinite, halloysite, allophane, and imogolite. The specific phases that formed and their amounts depended on factors such as initial $\mathrm{Al} / \mathrm{Si}$ ratio, $\mathrm{pH}$, temperature, and aging time. The proposed precipitation mechanism involves the slowing of Al hydroxide polymerization by formation of stable Al-organo complexes. 
These complexes are thought of as precursor species that have $\mathrm{Al}-\mathrm{O}$ (and possibly Si-O) bonds required for attachment of alumina and silicate sheets [12]. This eliminates the need for conversion of $\mathrm{Al}-\mathrm{OH}$ to $\mathrm{Al}-\mathrm{O}$ bonds in systems predisposed to $\mathrm{Al}$ hydroxide precipitation and facilitates the formation of required $\mathrm{Al}-\mathrm{O}-\mathrm{Si}$ linkages with the organic material acting as a "catalyst" which is subsequently recycled. Conversely, addition of organic acids such as citric [13] and more complex, naturally occurring fulvics and humics [14] were observed to inhibit the formation of well-defined phases during synthesis at $96-100^{\circ} \mathrm{C}$. The concentration of imogolite declined with increasing organic concentration, eventually giving way to the formation of only disordered aluminosilicates and pseudoboehmite $[13,14]$. However, to be applicable to natural systems synthesis at low temperature is required. Uniquely, this study was conducted at $25^{\circ} \mathrm{C}$ to systematically explore the effect of dissolved organic carbon (DOC) from natural humic acid (HA) on the formation of aluminosilicate minerals. Results isolated the role of initial chemical composition on aluminosilicate formation, as a first step in deconvoluting the complexity of this process in natural soils.

\section{Experimental Details}

Stock solutions for batch experiments were prepared by diluting in deionized water (DI) $1000 \mathrm{mg} / \mathrm{L} \mathrm{Al}$ in $\mathrm{HNO}_{3}$, and $1000 \mathrm{mg} / \mathrm{L} \mathrm{Si}$ in DI standard solutions. Suwannee River Humic Acid (SRHA, International Humic Substances Society) containing $53 \mathrm{wt} \% \mathrm{C}$ was dissolved in DI water to produce a $250 \mathrm{mg} / \mathrm{L}$ DOC stock. Though a river humic acid was chosen for this study, the carboxylic content can be similar to that of soil humic acids. A matrix of experimental binary and ternary solutions was prepared with variable $\mathrm{Al}$, $\mathrm{Si}$, and DOC concentrations (Table 1). Appropriate amounts of the stock solutions were mixed in the sequence $\mathrm{Si}$ and/or $\mathrm{Al}$ stock solution followed by DOC stock solution to yield a total volume of $80 \mathrm{~mL}$. Solution $\mathrm{pH}$ was adjusted to a value close to 6 ( $\pm 0.5 \mathrm{pH}$ unit) using $<0.5 \mathrm{~mL} 0.1$ or $1.0 \mathrm{M} \mathrm{NaOH}$, and initial concentrations were corrected for this addition. Time-series data indicated that aqueous concentrations of all components in filtered ( $0.2 \mu \mathrm{m}$ PTFE syringe filters) mixed solutions were invariant after $20 \mathrm{~h}$; thus, all experiments were conducted for this time period. Solutions were stirred only during preparation and prior to filtration. Aqueous $\mathrm{Al}$ and Si concentrations were determined by Inductively Coupled Plasma-Optical Emission Spectroscopy (ICP-OES) using a Perkin Elmer Optima 4300 instrument. All solutions were prepared and sampled in duplicate.

2.1. Thermodynamic Calculations. Based on results from small-volume batch experiments, solutions with select concentrations of $\mathrm{Al}, \mathrm{Si}$, and DOC were chosen to generate large amounts of precipitates for subsequent analysis (Table 1). The initial aqueous speciation and saturation states with respect to potential solid precipitates were calculated using Visual MINTEQ ver 2.53 with the Thermo.vdb database [15]. For all calculations, initial concentrations of $\mathrm{Al}, \mathrm{Si}$, and
TABLe 1: Concentrations of Al, Si, and DOC used for binary and ternary experiments (variable [DOC]), variables [Si] and [Al], and experiments used to generate precipitates for further analysis).

\begin{tabular}{lccc}
\hline & $\mathrm{Al}(\mathrm{mM})$ & $\mathrm{Si}(\mathrm{mM})$ & $\mathrm{DOC}(\mathrm{mg} / \mathrm{L})$ \\
\hline Binary solutions & - & 0.3 & 6 \\
& 0.3 & - & 6 \\
& 0.3 & 0.3 & - \\
Ternary solutions: variable [DOC] & 0.3 & 0.3 & 3 \\
& 0.3 & 0.3 & 6 \\
& 0.3 & 0.3 & 9 \\
\hline Variable [Si] & 0.3 & $0.05-1.5$ & - \\
Variable [Al] & 0.3 & $0.05-1.5$ & 6 \\
\hline Solutions for precipitate recovery & 0.5 & 0.5 & - \\
& $0.05-1.5$ & 0.3 & -1.5 \\
& 0.5 & 0.3 & 6 \\
\hline & 0.75 & 0.5 & - \\
& 0.75 & 0.5 & 6 \\
\hline
\end{tabular}

DOC were entered, along with any base required for $\mathrm{pH}$ adjustment. The $\mathrm{pH}$ was calculated from the charge and mass balance in solution prior to precipitation, that is, the $\mathrm{H}^{+}$concentration was adjusted until the charge difference was $\leq 0.01 \%$. For DOC-bearing solutions, the Stockholm Humic Model (SHM) [16] was used to model metalhumic complexation. Acid dissociation constants for SRHA carboxylic and phenolic functional groups available from IHSS [17] were included.

2.2. Evaluation of Precipitate Phases. Experiments designed to generate sufficient material for compositional and mineralogical analysis (Table 1) were prepared in an $800 \mathrm{~mL}$ volume in triplicate and were treated with $<1 \mathrm{~mL} 10 \mathrm{~N}$ $\mathrm{NaOH}$ for $\mathrm{pH}$ adjustment. After $20 \mathrm{~h}$, each solution was vacuum-filtered using a $0.2 \mu \mathrm{m}$ polycarbonate filter, the filtrate sampled for $\mathrm{Al}$ and $\mathrm{Si}$ analysis, and the precipitate recovered. The final mass of precipitate was placed in a drying oven at $40^{\circ} \mathrm{C}$ for several hours to expedite evaporation of excess moisture, then ground gently using a mortar and pestle. A portion of sample was dissolved using $0.1 \mathrm{M} \mathrm{HNO}_{3}$ and the $\mathrm{Al}$ and $\mathrm{Si}$ concentrations determined by ICP-OES analysis. Total C content was determined using a Carlo Erba 2500 CHNS Elemental Analyzer. X-ray diffraction (XRD) data were collected from $2-65^{\circ}$ 2-theta with a step size of $0.02^{\circ}$ using a Siemens D5000 X-ray diffractometer. Fourier transform infrared (FTIR) spectroscopy data were collected in transmission mode for samples in a KBr background using a Perkin Elmer Spectrum 100 spectrometer.

Both ${ }^{29} \mathrm{Si}$ and ${ }^{27} \mathrm{Al}$ nuclear magnetic resonance spectroscopy (NMR) data were collected for generated solids. The ${ }^{29} \mathrm{Si}$ single-pulse magic angle spinning (SP/MAS) and ${ }^{29} \mathrm{Si}\left\{{ }^{1} \mathrm{H}\right\}$ cross-polarization magic angle spinning 
(CP/MAS) spectra were collected with a $400 \mathrm{MHz}(9.4 \mathrm{~T})$ Varian Inova spectrometer operating at $79.5 \mathrm{MHz}$ for ${ }^{29} \mathrm{Si}$ using a Varian/Chemagnetics T3 sample probe assembly configured for $3.2 \mathrm{~mm}$ (o.d.) rotors. The SP/MAS spectra were collected under quantitative acquisition conditions using a $90^{\circ}$ pulse $(5 \mu \mathrm{s})$ and $180 \mathrm{~s}$ relaxation delay at a spinning rate of $10 \mathrm{kHz}$. The $\mathrm{CP} / \mathrm{MAS}$ spectra were obtained at spinning rates of 5 and $10 \mathrm{kHz}$ using a ramp of the transverse ${ }^{1} \mathrm{H}$ field during polarization transfer for contact times ranging from 0.5 to $15 \mathrm{~ms}$. For the ${ }^{27} \mathrm{Al}$ SP/MAS NMR spectra, a $500 \mathrm{MHz}(11.7 \mathrm{~T})$ Varian Infinity Plus spectrometer was used, operating at $130.3 \mathrm{MHz}$ with the sample spinning at $18 \mathrm{kHz}$ in $3.2 \mathrm{~mm}$ rotors. The acquisition parameters consisted of $1.0 \mu$ s pulses $(\pi / 12)$ and a $1.0 \mathrm{~s}$ relaxation delay, which correspond to uniform excitation and full relaxation of the central transition. Additional spectra were taken for the $1.0 \mathrm{mM} \mathrm{Al}$ samples at $217 \mathrm{MHz}(19.5 \mathrm{~T}$; Center for Interdisciplinary Magnetic Resonance, National High Magnetic Field Laboratory, Tallahassee, FL, USA). These high-field spectra were taken at a $10 \mathrm{kHz}$ spinning rate $(4 \mathrm{~mm}$ spinning system) under low-power conditions using $4 \mu$ s pulses and $0.5 \mathrm{~s}$ relaxation delay for a total of 128 acquisitions.

\section{Results}

3.1. Al and Si Removal from Binary and Ternary Solutions. Results for ternary Al-Si-DOC and binary Al-Si, Al-DOC and $\mathrm{Si}$-DOC experiments show that for all systems, $\mathrm{Si}$ is less susceptible to removal from the aqueous phase relative to $\mathrm{Al}$ (Figure 1). Comparison of results from the binary $\mathrm{Al}-\mathrm{Si}$, $\mathrm{Si}-\mathrm{DOC}$, and Al-DOC experiments indicates that aqueous $\mathrm{Si}$ concentration is reduced in the presence of Al but not DOC, whereas $\mathrm{Al}$ is removed from solution in the presence of $\mathrm{Si}$, and to a greater extent in the presence of DOC.

Equal amounts of $\mathrm{Al}$ and $\mathrm{Si}$ precipitated from $\mathrm{Al}-\mathrm{Si}$ solutions with 0 or $3 \mathrm{mg} / \mathrm{L}$ DOC. As DOC concentration increased from 3 to $6 \mathrm{mg} / \mathrm{L}$, removal of both $\mathrm{Al}$ and $\mathrm{Si}$ was enhanced. At $9 \mathrm{mg} / \mathrm{L}$ DOC no additional $\mathrm{Al}$ was removed, and aqueous $\mathrm{Si}$ concentrations increased slightly, relative to the $6 \mathrm{mg} / \mathrm{L}$ DOC solution. These results suggest that removal of both $\mathrm{Al}$ and $\mathrm{Si}$ was optimized in the $6 \mathrm{mg} / \mathrm{L}$ DOC solution relative to binary and other ternary solutions, therefore $6 \mathrm{mg} / \mathrm{L}$ DOC was used in subsequent experiments in which initial concentrations of $\mathrm{Al}$ and $\mathrm{Si}$ were varied. The $\mathrm{Al} / \mathrm{Si}$ ratios of precipitates from 0,3 , and $6 \mathrm{mg} / \mathrm{L} \mathrm{DOC}$ solutions are 2.2-2.3, suggesting that precipitates formed both in the absence and presence of DOC may be similar in composition. The slightly higher $\mathrm{Al} / \mathrm{Si}$ ratio of 2.8 in precipitates from $9 \mathrm{mg} / \mathrm{L}$ DOC solutions suggests the precipitation of additional $\mathrm{Al}$, possibly caused by the higher concentration of DOC.

Comparing the results from binary and ternary systems indicates that in the latter $\mathrm{Al}$ may precipitate both as aluminosilicate and alumino-organic complexes. As Si does not appear to form insoluble complexes with DOC, enhanced Si removal in Al-Si-DOC solutions, with DOC $>3 \mathrm{mg} / \mathrm{L}$, relative to Al-Si solutions appears to result by the formation of aluminosilicate complexes which may bind to the DOC

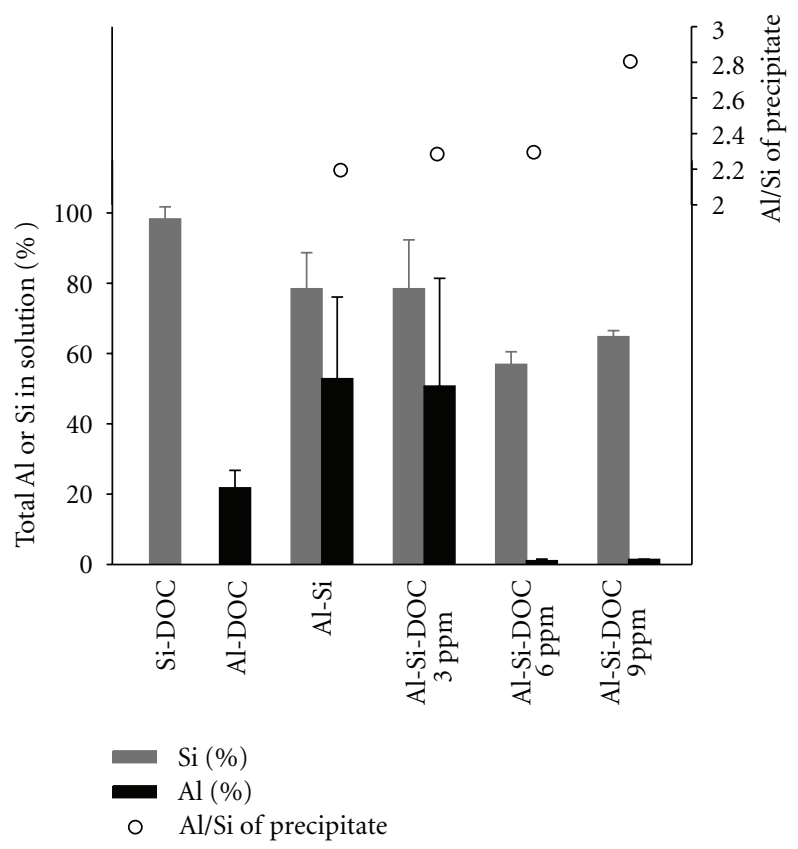

Figure 1: Percentage of total aqueous $\mathrm{Al}$ and $\mathrm{Si}$ in solution (bars) and $\mathrm{Al} / \mathrm{Si}$ ratio (open symbols) for binary and ternary solutions with $\mathrm{Al}=\mathrm{Si}=0.3 \mathrm{mM}$ and $0-9 \mathrm{mg} / \mathrm{L}$ DOC.

by an Al-bridging mechanism (i.e., Si-Al-DOC). Coprecipitation of aluminosilicate with precipitating organics may also occur. Hence, significant reduction in both $\mathrm{Al}$ and $\mathrm{Si}$ concentrations in Al-Si-DOC solutions is likely caused by multiple complexation and precipitation pathways.

\subsection{The Effect of Varying Al or Si Concentration in Solutions} with 0 or $6 \mathrm{mg} / \mathrm{L}$ DOC. The effect of variable Si concentration from 0.05 to $1.5 \mathrm{mM} \mathrm{Si}$ was evaluated at a fixed initial $\mathrm{Al}$ concentration of $0.3 \mathrm{mM}$ and fixed DOC concentration of 0 or $6 \mathrm{mg} / \mathrm{L}$. The amount of Si remaining in solution after $20 \mathrm{~h}$ was slightly below the initial value in all cases with no obvious effect of DOC (Figure 3(a)). The final concentration of $\mathrm{Al}$ remained much lower than the initial value regardless of initial $\mathrm{Si}$, with a slightly higher value (less removal) only at $1.5 \mathrm{mM} \mathrm{Si}$ (Figure 3(b)). Below $0.3 \mathrm{mM}$ initial Si, aqueous $\mathrm{Al}$ concentration remained slightly higher for Al-Si relative to Al-Si-DOC solutions. This is consistent with the enhanced removal of $\mathrm{Al}$ in DOC solutions.

The effect of variable $\mathrm{Al}$ concentration from 0.05 to $1.5 \mathrm{mM}$ was evaluated at an initial Si concentration fixed at $0.5 \mathrm{mM}$, a value anticipated to be sufficient for observing potential interactions with the higher concentrations of Al. Total Si concentration decreased with increasing initial $\mathrm{Al}$ (Figure 3(c)), with comparable behavior for 0 and $6 \mathrm{mg} / \mathrm{L}$ DOC solutions except from 0.6 to $0.9 \mathrm{mM}$ initial $\mathrm{Al}$ where the final Si concentration of the Al-Si solutions without DOC increased abruptly (Figure 3(c)). A similar abrupt increase occurred for final $\mathrm{Al}$ in the same $\mathrm{Al}-\mathrm{Si}$ solutions (Figure 3(d)). In the Al-Si-DOC solutions, the Si concentration abruptly increased at $1 \mathrm{mM}$ initial $\mathrm{Al}$ (Figure 3(c)) to a value similar to that of the DOC-free solution. In 


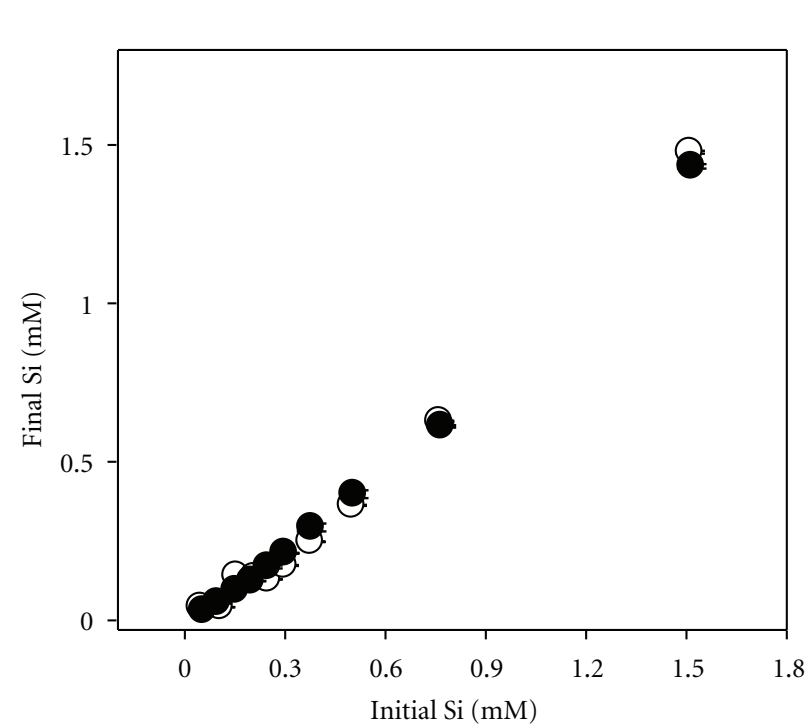

(a)

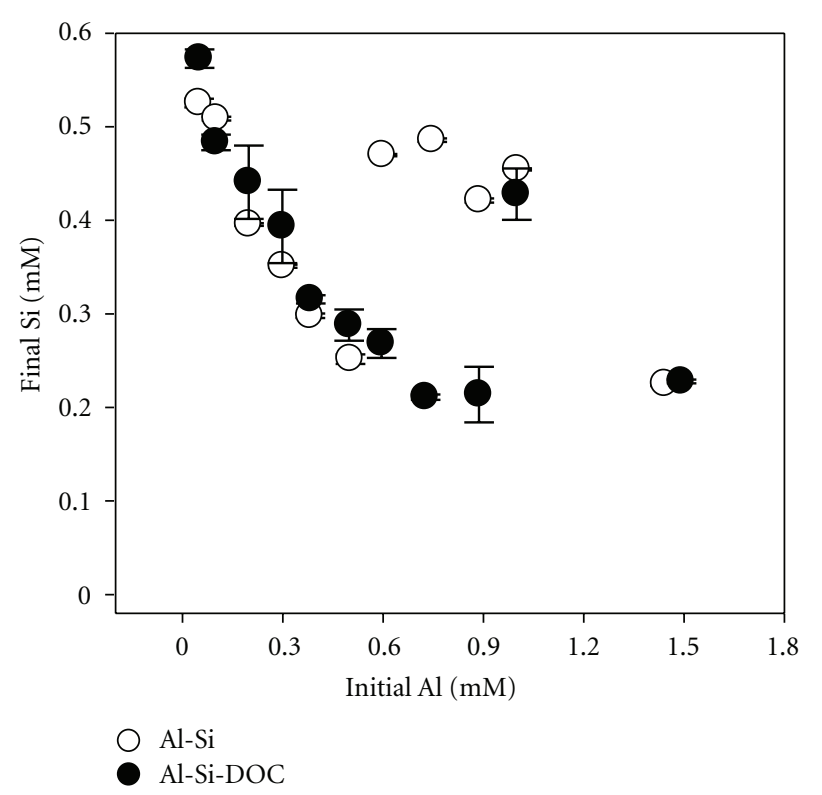

(c)
Initial Si $(\mathrm{mM})$

$\begin{array}{llllllll}0 & 0.3 & 0.6 & 0.9 & 1.2 & 1.5 & 1.8\end{array}$

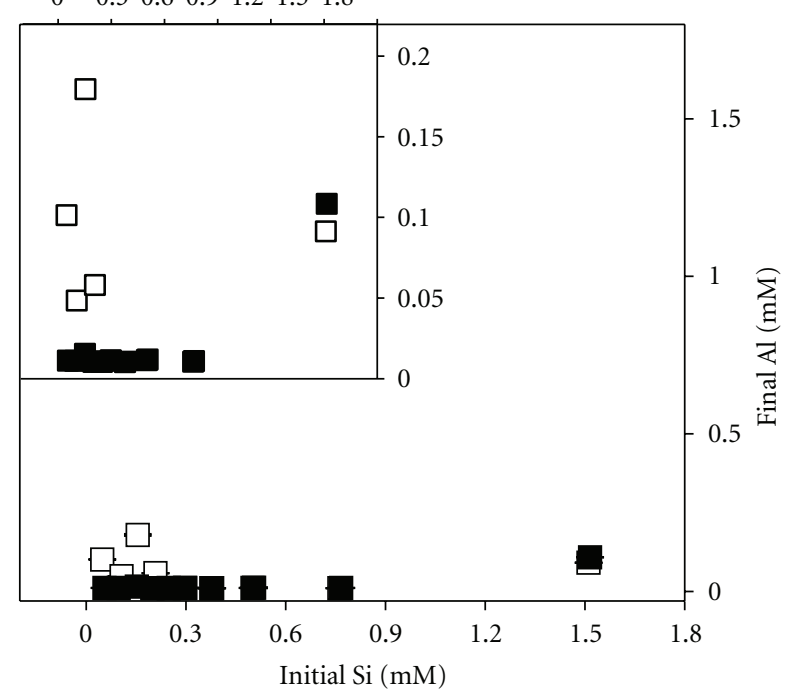

(b)

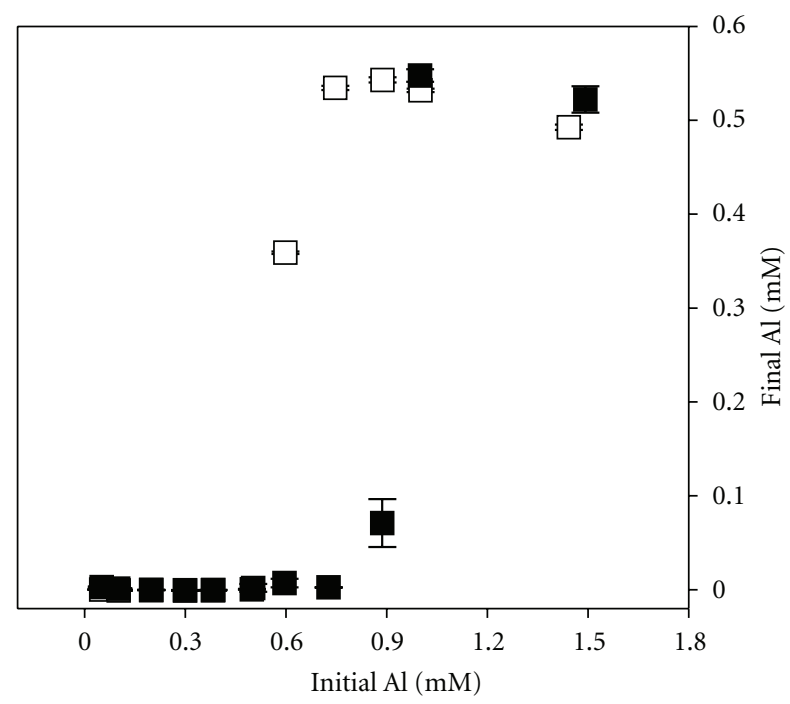

$\mathrm{Al}-\mathrm{Si}$

Al-Si-DOC

Figure 2: Final concentrations of (a) Si and (b) Al for 0.05-1.5 mM Si, $0.3 \mathrm{mM} \mathrm{Al}$; (c) Si and (d) Al at 0.05-1.5 mM Al, 0.5 mM Si; in Al-Si $(0 \mathrm{mg} / \mathrm{L} \mathrm{DOC})$ and Al-Si-DOC (6 mg/L DOC) solutions.

these solutions, $\mathrm{Al}$ concentration fell rapidly to a low value and remained relatively constant up to $1 \mathrm{mM}$ initial $\mathrm{Al}$ (Figure 3(d)), above which it also increased to values similar to those in the DOC-free solution.

Solids recovered from $\mathrm{Al}-\mathrm{Si}$ and $\mathrm{Al}-\mathrm{Si}-\mathrm{DOC}$ solutions with $0.5,0.75$, and $1.0 \mathrm{mM}$ initial $\mathrm{Al}$ were analyzed to investigate further the deviation between $\mathrm{Al}-\mathrm{Si}$ and $\mathrm{Al}-\mathrm{Si}-\mathrm{DOC}$ systems observed over the initial $\mathrm{Al}$ concentration range of $0.6-1.0 \mathrm{mM}$.
3.3. Speciation in and Saturation States of Initial Solutions Containing 0.5, 0.75, and $1.0 \mathrm{mMAl}, 0.5 \mathrm{mMSi}$, and 0 or $6 \mathrm{mg} / \mathrm{L}$ DOC. Thermodynamic modeling was used to estimate initial aqueous speciation and predicted precipitates for the $0.5,0.75$, and $1.0 \mathrm{mM} \mathrm{Al}$ solutions with $0.5 \mathrm{mM}$ $\mathrm{Si}$ and 0 or $6 \mathrm{mg} / \mathrm{L}$ DOC. The dominant initial aqueous $\mathrm{Al}$ and $\mathrm{Si}$ species are $\mathrm{Al}(\mathrm{OH})_{2}{ }^{+}$and $\mathrm{H}_{4} \mathrm{SiO}_{4}{ }^{0}$ (Table 2). With increasing $\mathrm{Al}$ concentration, the concentration of $\mathrm{AlH}_{3} \mathrm{SiO}_{4}{ }^{2+}$ complexes increases subtly. The fraction of polymeric $\mathrm{Al}_{3}(\mathrm{OH})_{4}{ }^{5+}$ increases by a factor of 10 when the 


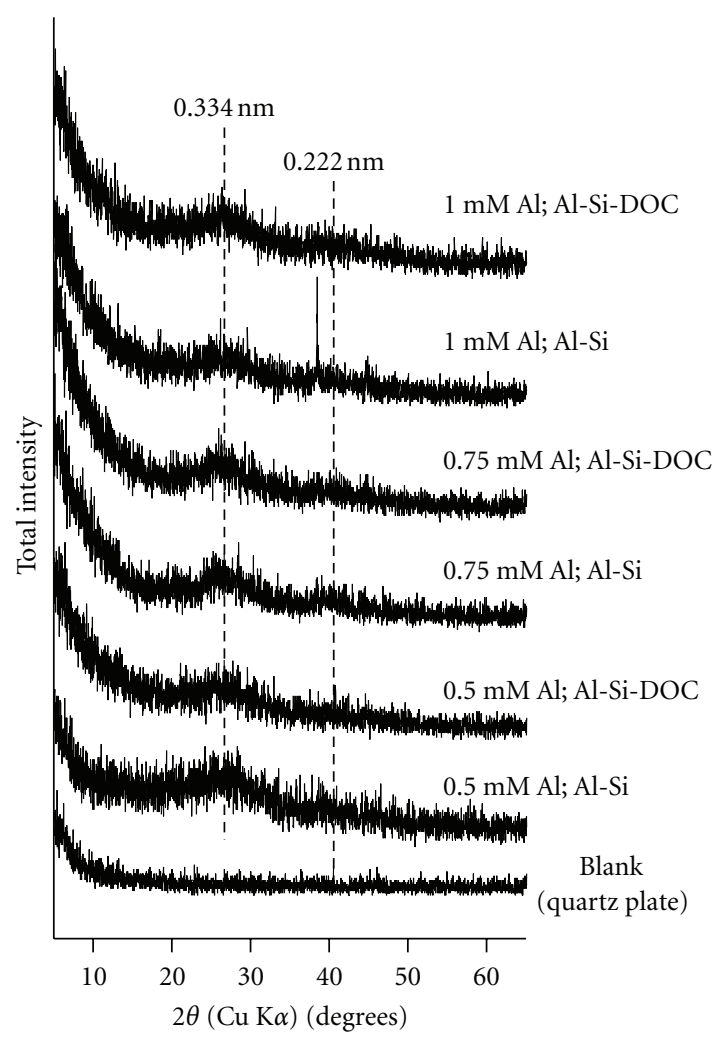

FIGURE 3: X-ray diffraction patterns for solids derived from Al-Si and Al-Si-DOC solutions with $0.5,0.75$, and $1.0 \mathrm{mM} \mathrm{Al} ; 0.5 \mathrm{mM} \mathrm{Si}$; 0 or $6 \mathrm{mg} / \mathrm{L}$ DOC.

initial $\mathrm{Al}$ concentration is doubled from 0.5 to $1.0 \mathrm{mM}$. For initial Al-Si-DOC solutions, the overall fractions of dominant species, $\mathrm{Al}(\mathrm{OH})_{2}{ }^{+}, \mathrm{Al}(\mathrm{OH})_{3}{ }^{0}$, and $\mathrm{Al}(\mathrm{OH})_{4}{ }^{-}$, are somewhat lowered relative to those in $\mathrm{Al}-\mathrm{Si}$ solutions, but otherwise the speciation trends are similar. Speciation of $\mathrm{Al}$ as the aluminum tridecamer $\mathrm{Al}_{13}$ was negligible as formation of this species is limited in the presence of $\mathrm{Si}[18]$ and HA [19]. The calculated $\mathrm{pH}$ for all solutions ranged from $\mathrm{pH} 6.03$ to 6.09 , consistent with the measured $\mathrm{pH}$ of $6.00 \pm 0.5$ for all samples.

The predicted species for $\mathrm{Al}$ complexed with SRHA are primarily bidentate $\mathrm{HA}_{2} \mathrm{AlOH}$ and $\mathrm{HA}_{2} \mathrm{Al}^{+}$along with a small fraction $(<1 \%)$ of electrostatically bound Al. The fraction of Al-HA complexes decreases with increasing initial $\mathrm{Al}$ concentration; however, the absolute concentration of Al complexed to HA, including electrostatic species, is $\sim 0.027 \mathrm{mM}$ for all initial $\mathrm{Al}$ concentrations (Table 2). The concentration of DOC involved in this complexation is about $0.053 \mathrm{mM}$, corresponding to $0.6 \mathrm{mg} / \mathrm{L}$ or one-tenth of the initial DOC in solution.

The ${ }^{13} \mathrm{C}$ NMR analysis of SRHA [23] indicates that $15 \%$ of the $\mathrm{C}$ occurs as carboxyl functional groups. For $6 \mathrm{mg} / \mathrm{L}(0.5 \mathrm{mM})$ DOC solutions approximately $0.07 \mathrm{mM}$ of $\mathrm{C}$ would be associated with these groups. If $\mathrm{Al}$ complexes primarily with carboxyl functional groups [24], then the maximum concentration of $\mathrm{C}$ available for complexation with $\mathrm{Al}$ is $0.07 \mathrm{mM}$. Thus, the thermodynamic calculations suggest that $\sim 70 \%$ of this $\mathrm{C}(0.05 \mathrm{mM})$ may be directly bonded to $\mathrm{Al}$ to form bidentate $\mathrm{Al}-\mathrm{HA}$ complexes in solution.

The supersaturated mineral phases for all initial Al-Si and Al-Si-DOC solutions are kaolinite, halloysite, imogolite, allophane, diaspore, boehmite, gibbsite, amorphous $\mathrm{Al}(\mathrm{OH})_{3}$, and quartz. All solutions were undersaturated with respect to amorphous $\mathrm{SiO}_{2}$. Though thermodynamically feasible, not all predicted phases will precipitate under the given solution conditions. For example, spontaneous precipitation of quartz is likely only in supersaturated solutions [25] well above the concentrations studied here, whereas that of diaspore is rare in the absence of stabilizing substituting ions such as Fe [26].

3.4. Precipitates from Initial Solutions with 0.5, 0.75, and $1.0 \mathrm{mM} \mathrm{Al}, 0.5 \mathrm{mMSi}$, and 0 or $6 \mathrm{mg} / \mathrm{L}$ DOC. Solids formed from the Al-Si solutions were white to colorless, whereas those from Al-Si-DOC solutions were dark brown, similar in color to the initial solutions. All precipitates were gel-like in consistency. Of Al, $\mathrm{Si}$, and $\mathrm{C}, \mathrm{Al}$ was highest in concentration by weight (wt \%) in all samples (Table 3 ) and was highest for the samples formed in initial $0.75 \mathrm{mM} \mathrm{Al}$ solutions with and without DOC. The wt \% Si decreased with increasing initial $\mathrm{Al}$ concentration for solids formed in $\mathrm{Al}-\mathrm{Si}$ solutions and was highest in the solid formed in the $0.75 \mathrm{mM} \mathrm{Al}$ Si-DOC solution. The wt \% C in the solids also decreased with increasing initial $\mathrm{Al}$ consistent with the corresponding decrease in the calculated fraction of Al-HA complexes and suggesting that these complexes are precursors to Al-HA precipitates in the solids.

Precipitates from $0.5 \mathrm{mM}$ initial $\mathrm{Al}$ solutions that contained DOC had less mass $(58 \mathrm{mg}), \mathrm{Al}$, and Si than precipitates $(72 \mathrm{mg})$ from the solutions without DOC. The $\mathrm{Al} / \mathrm{Si}$ mole ratio for the precipitates was 2.2. The mole ratio of $\mathrm{Al} / \mathrm{C}$ in the precipitate from the DOC-bearing solution was 0.7. The lower mass of the Al-Si-DOC solids suggests that Al-HA complexation inhibits or slows the formation of aluminosilicate phases, but does not change the bulk inorganic composition of the precipitate compared to DOCfree solutions. If the HA is a simple coprecipitate in the solids, it would be associated with about $1 \mathrm{wt} \%$ of the precipitated $\mathrm{Al}$, assuming the same bidentate stoichiometry with carboxyl groups as in the soluble Al-HA species. This would lower the $\mathrm{Al} / \mathrm{Si}$ ratio in the inorganic precipitate to $\sim 2$.

At $0.75 \mathrm{mM}$ initial $\mathrm{Al}$, again the total mass of precipitate from the Al-Si solution was greater $(190 \mathrm{mg})$ compared to the mass $(169 \mathrm{mg})$ precipitated from the Al-Si-DOC solution. The fraction of precipitated $\mathrm{Al}$ and $\mathrm{Si}$ is higher in the Al-SiDOC solid compared to the $\mathrm{Al}-\mathrm{Si}$ solid, but the $\mathrm{Al} / \mathrm{Si}$ ratio is the same within uncertainty. This $\mathrm{Al} / \mathrm{Si}$ ratio is, however, slightly higher than the ratios in the $0.5 \mathrm{mM} \mathrm{Al}$ precipitates. Assuming an $\mathrm{Al} / \mathrm{Si}$ mole ratio of 2 in the inorganic part of the precipitate, the excess $\mathrm{Al}$ is too high by a factor of $\sim 8$ to be solely in the form of bidentate Al-HA complexes, assuming there is no fractionation (i.e., selective precipitation of smaller molecules with higher proportions of Al-binding sites) of the HA during precipitation. This suggests that a small amount of an Al-(oxy)hydroxide phase may have 
TABLE 2: Speciation of $\mathrm{Al}$ and $\mathrm{Si}$ in $0.5,0.75$, and $1.0 \mathrm{mM} \mathrm{Al} ; 0.5 \mathrm{mM}$ Si solutions with 0 (Al-Si) and $6 \mathrm{mg} / \mathrm{L}$ (Al-Si-DOC) as calculated using Visual MINTEQ ver 2.53 with the Thermo.vdb database ${ }^{1}$.

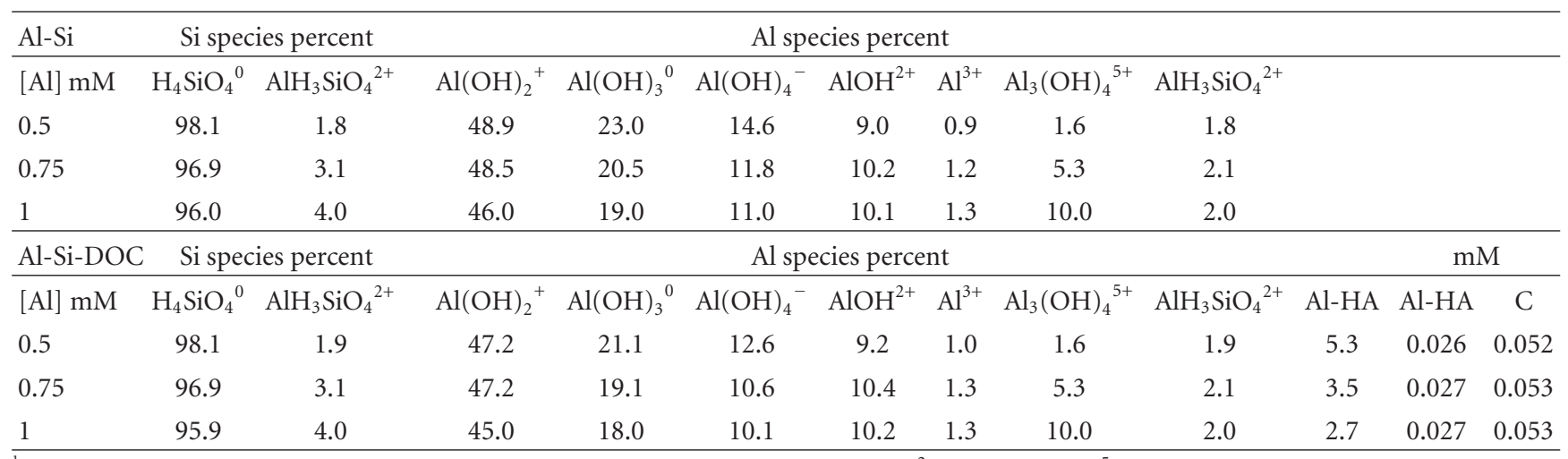

${ }^{1}$ Source of thermodynamic data for aqueous species: $\mathrm{Al}$ hydrolysis species [20]; $\mathrm{AlH}_{3} \mathrm{SiO}_{4}{ }^{2+}$ [21]; $\mathrm{Al}_{3}(\mathrm{OH})_{4}{ }^{5+}$ [22]. Organic complexation was calculated using the Stockholm Humic Model [16].

TABLE 3: Composition of precipitates derived from solutions with initial 0.5, 0.75, and $1.0 \mathrm{mM}$ initial Al; $0.5 \mathrm{mM}$ initial Si and 0 or $0.5 \mathrm{mM}$ $(6 \mathrm{mg} / \mathrm{L})$ DOC.

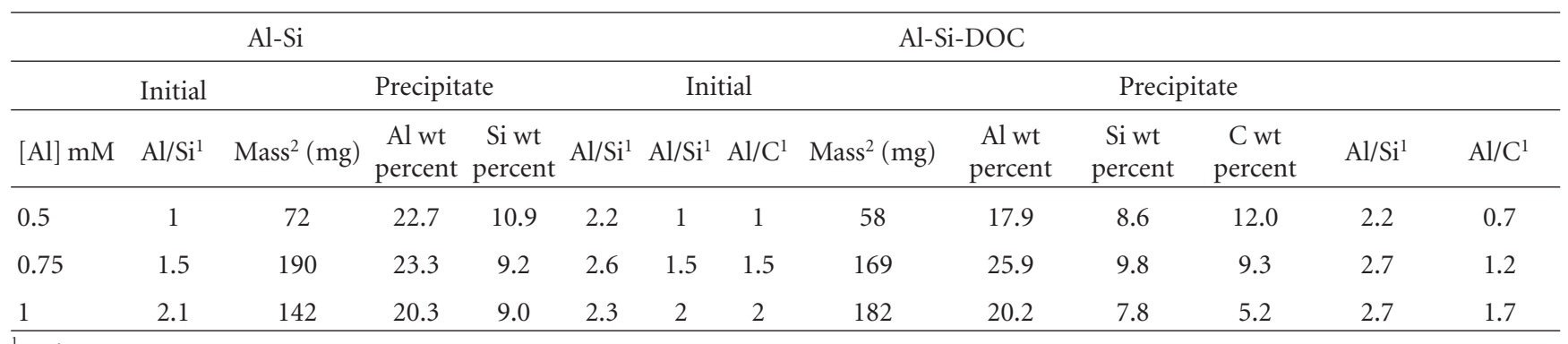

${ }^{1}$ Mole ratios.

${ }^{2}$ Uncertainty is $\pm 1 \mathrm{mg}$.

formed as predicted by the thermodynamic calculations. DOC appears to promote aluminosilicate precipitation, but the overall composition of the precipitate is similar to that of DOC-free solids.

At $1.0 \mathrm{mM}$ initial $\mathrm{Al}$, the mass of precipitate $(142 \mathrm{mg})$ from the Al-Si solutions was less than that $(182 \mathrm{mg}$ ) from the Al-Si-DOC solutions. The $\mathrm{wt}_{\mathrm{t}} \%$ of precipitated $\mathrm{Al}$ is the same for both DOC-free and DOC-bearing solids, but less than that for solids formed from solutions with initial $\mathrm{Al}$ of $0.75 \mathrm{mM}$. The $\mathrm{Al} / \mathrm{Si}$ ratio of the Al-Si-DOC sample is similar to that of the solids formed in the initial $0.75 \mathrm{mM} \mathrm{Al}$ solutions. However, the $\mathrm{Al} / \mathrm{C}$ ratio indicates less precipitated $\mathrm{C}$ relative to the 0.5 and $0.75 \mathrm{mM}$ samples, which correlates with the decrease in the calculated fraction of Al-HA complexes in solution with increasing initial Al. Again, assuming an $\mathrm{Al} / \mathrm{Si}$ ratio in the aluminosilicate of 2 and no fractionation of the HA during precipitation, the excess precipitated $\mathrm{Al}$ is about a factor of 6 too high to be complexed only to carboxyl $\mathrm{C}$ in coprecipitated HA suggesting the formation of a minor amount of Al-(oxy)hydroxide.

3.4.1. XRD Analysis. X-ray powder diffraction patterns show that all solids exhibited low crystallinity, with no notable differences as a function of $\mathrm{Al}$ concentration or in the absence or presence of DOC (Figure 2). Broad peaks centered at approximately $0.334 \mathrm{~nm}$ and $0.222 \mathrm{~nm}$, characteristic of allophane $[6,7,27]$, occur in all samples. Aluminum-rich allophanes $\left(\mathrm{Al}_{2} \mathrm{O}_{3} \cdot \mathrm{xSiO}_{2} \cdot \mathrm{yH}_{2} \mathrm{O}(x=1 ; y=2-5)\right)$ classified as protoimogolite or imogolite-like allophane [28] can have $\mathrm{Al} / \mathrm{Si}$ ratios ranging from 2.3 to 2.7 [29], consistent with the observed range of 2.2 to 2.7. The observed XRD reflections are also common to imogolite, although there are additional imogolite reflections $[30,31]$ that are absent in the XRD patterns. The additional peaks are also significantly less intense than the observed peaks and would be close to background in these samples. Thermodynamic calculations indicated initial supersaturation with respect to allophone, imogolite, halloysite, and kaolinite. However, equilibration of halloysite and kaolinite is slow at room temperature $[2,12]$, whereas allophane readily forms in oversaturated solutions [31].

3.4.2. FTIR Analysis. Sample spectra reveal bands at $\sim 3500$, 970,570 , and $430 \mathrm{~cm}^{-1}$, characteristic of allophane and imogolite $[8,32]$ (Figure 4). The diffuse band at 3000$3800 \mathrm{~cm}^{-1}$ is indicative of $\mathrm{OH}$ stretching of $\mathrm{Al}-\mathrm{OH}, \mathrm{Si}-$ $\mathrm{OH}$, and water [33], with an additional water band at $\sim 1600 \mathrm{~cm}^{-1}$. The peak at $970 \mathrm{~cm}^{-1}$ is attributed to $\mathrm{Si}-\mathrm{O}$ 


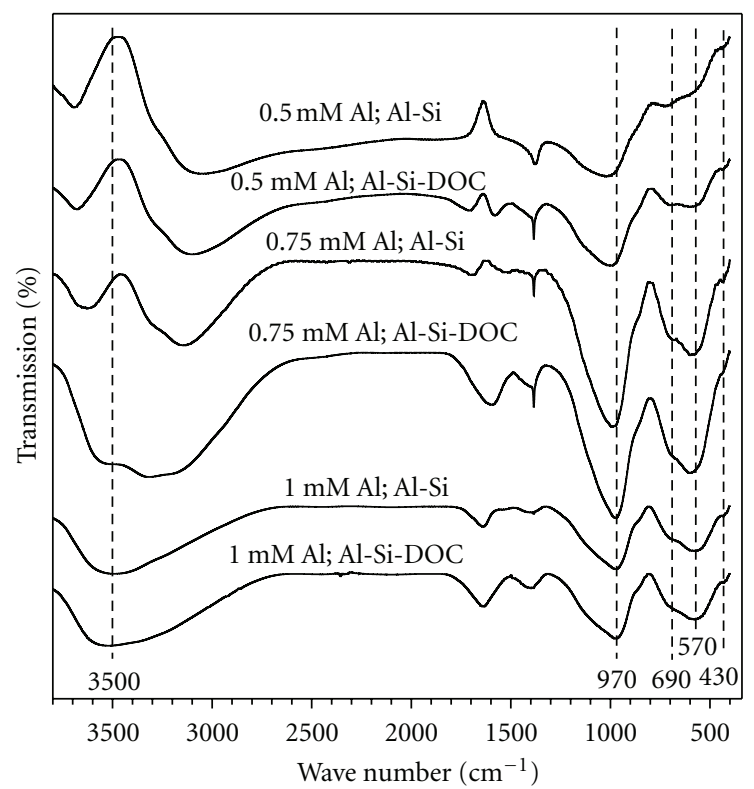

FIGURE 4: FTIR spectra for solids derived from Al-Si and Al-Si-DOC solutions with $0.5,0.75$ and $1.0 \mathrm{mM} \mathrm{Al} ; 0.5 \mathrm{mM} \mathrm{Si}$; and 0 or $6 \mathrm{mg} / \mathrm{L}$ DOC.

stretching and shifts to higher wavenumbers at lower $\mathrm{Al} / \mathrm{Si}$ ratios with the peak for $0.5 \mathrm{mM}$ initial $\mathrm{Al}$ samples closer to $1000 \mathrm{~cm}^{-1}$. The peaks in the $800-400 \mathrm{~cm}^{-1}$ range are from $\mathrm{Si}-\mathrm{O}-\mathrm{Al}$ and $\mathrm{Si}-\mathrm{O}-\mathrm{Si}$ stretching. The broad band at $570 \mathrm{~cm}^{-1}$ with shoulders at 690 and $430 \mathrm{~cm}^{-1}$ indicates an imogolite-like structure observed in natural allophane and imogolite [27]. Compared to allophane, imogolite peaks are sharper with doublets at 970 and $570 \mathrm{~cm}^{-1}[32,34]$. Sharper peaks for $0.75 \mathrm{mM}$ initial $\mathrm{Al}$ solids may indicate more imogolite or imogolite-like material in these samples. The broadest peaks are observed for the $0.5 \mathrm{mM}$ initial $\mathrm{Al}$ solid with no DOC, indicative of less imogolite-like material in this sample.

3.4.3. NMR Analysis. The ${ }^{29} \mathrm{Si}$ SP MAS/NMR spectra of all the precipitates contain a narrow peak at a chemical shift of $\delta_{\mathrm{Si}-29}=-78.3 \mathrm{ppm}(1.8 \mathrm{ppm}$ full width at half maximum; FWHM) plus a broad signal at more negative chemical shifts that can be represented by two broad peaks, near $-82 \mathrm{ppm}$ and $-89 \mathrm{ppm}$, and 9-17 ppm FWHM, in varying proportions (Figure 5). The narrow peak is characteristic of imogolite-like Si environments, in which a silicate tetrahedron is coordinated to three 6-coordinated $\mathrm{Al}$ ions and one hydroxyl ion $[35,36]$. The broad peaks arise from polymerized $\mathrm{Si}$, and resemble closely those reported previously for natural allophane $[36,37]$ and also for synthetic hydroxy-aluminosilicates $[38,39]$. For the precipitates from solutions with $0.75 \mathrm{mM}$ initial $\mathrm{Al}$, (Figures 5(c) and 5(d)) the imogolite-like environments represent a greater proportion of the Si (20-23\%) than for those with $1.0 \mathrm{mM}$ initial $\mathrm{Al}(18-21 \%$; Figures 5(e) and 5(f)) and $0.5 \mathrm{mM}$ initial $\mathrm{Al}$ (10\%; Figures 5(a) and 5(b); Table 4). For solids from $0.75 \mathrm{mM}$ and $1.0 \mathrm{mM}$ solutions, the fitted intensity of the

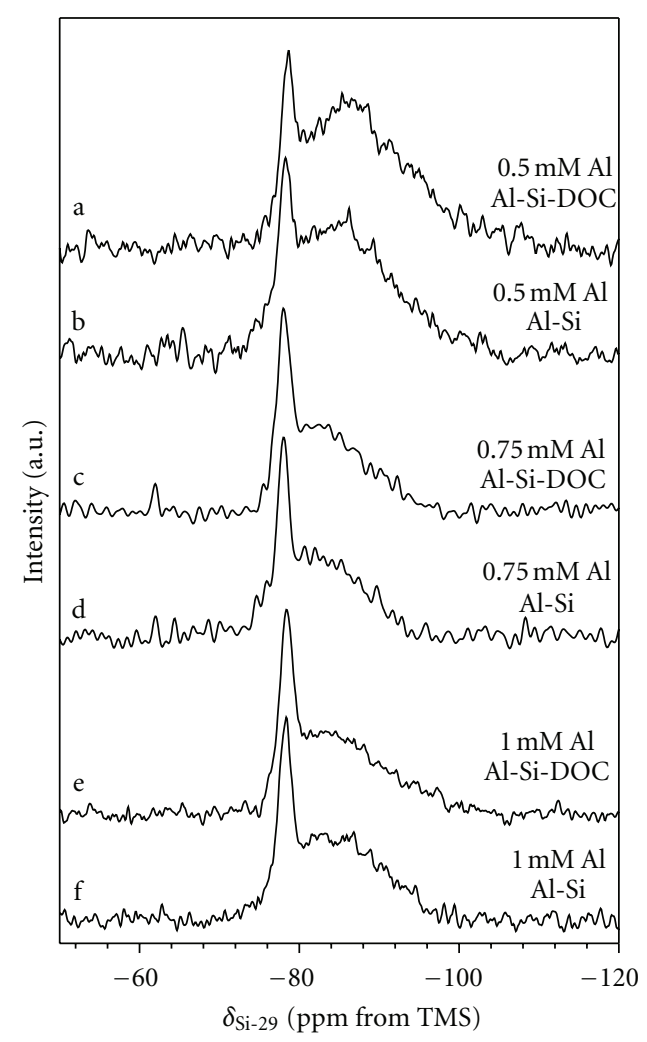

FIGURE 5: ${ }^{29} \mathrm{Si}$ SP/MAS NMR spectra of precipitates from solutions with $0.5 \mathrm{mM} \mathrm{Si}$ and (a-b) $0.5 \mathrm{mM} \mathrm{Al}$; (c-d) $0.75 \mathrm{mM} \mathrm{Al}$; (e-f) $1.0 \mathrm{mM} \mathrm{Al}$; with and without $6 \mathrm{mg} / \mathrm{L}$ DOC as indicated. All spectra were taken under quantitative conditions with a $180 \mathrm{~s}$ relaxation delay and $10 \mathrm{kHz}$ spinning rate.

imogolite-like peak is somewhat higher for the Al-Si-DOC relative to the $\mathrm{Al}-\mathrm{Si}$ samples. Although the difference is subtle, the values for Al-Si-DOC samples are consistently higher than those of Al-Si samples (Table 4). For all pairs of Al-Si/Al-Si-DOC samples, the average chemical shift of the broad component was slightly more negative by 1-2 ppm for the Al-Si-DOC solids suggesting an increased tetrahedral $\mathrm{Si} / \mathrm{Al}$ ratio in the polymerized structures. The ${ }^{29} \mathrm{Si}\left\{{ }^{1} \mathrm{H}\right\}$ CP/MAS spectra (not shown) are essentially identical to the corresponding SP/MAS spectra except for some minor differences in relative intensity, which varied only slightly with the NMR experimental contact time.

The aluminosilicate precipitates have ${ }^{27} \mathrm{Al}$ MAS/NMR spectra that contain peaks centered near 5.5, 33, and $59 \mathrm{ppm}$, which are characteristic of $\mathrm{Al}$ in 6-, 5-, and 4coordination, respectively (Figure 6). These values are the observed peak positions at $11.7 \mathrm{~T}$. The peaks for 4- and 6coordinated $\mathrm{Al}\left(\mathrm{Al}^{\mathrm{IV}}\right.$ and $\left.\mathrm{Al}^{\mathrm{VI}}\right)$ are similar to those reported for natural imogolite and allophane $[29,36]$ and for synthetic amorphous hydroxyaluminosilicates [38]. In addition to $\mathrm{Al}^{\mathrm{IV}}$ and $\mathrm{Al}^{\mathrm{VI}}$, a peak for 5-coordinated $\mathrm{Al}\left(\mathrm{Al}^{\mathrm{V}}\right)$ from allophane similar to that observed here has been reported [40] but would have been difficult to detect at the slower spinning rates used in the earlier studies. The integrated intensities of the three resonances were estimated by fitting the center 
TABLE 4: The percentage of imogolite-like Si from ${ }^{29} \mathrm{Si}$ NMR, corresponding to the integrated relative intensity of the peak at -78.3 ppm. The $\delta_{\mathrm{Si}-29}$ of the gel component is the weighted average of the broad signal, excluding the imogolite-like peak. Also reported is the percentage of $\mathrm{Al}$ in 4-, 5-, and 6-fold coordination from ${ }^{27} \mathrm{Al} \mathrm{NMR.}$

\begin{tabular}{|c|c|c|c|c|c|}
\hline \multirow{2}{*}{ Sample } & \multicolumn{2}{|c|}{${ }^{29} \mathrm{Si} \mathrm{NMR}$} & \multicolumn{3}{|c|}{${ }^{27} \mathrm{Al}$ NMR } \\
\hline & Imogolite-like Si percent & $\delta_{\mathrm{Si}-29}$ gel & $\mathrm{Al}^{(\mathrm{IV})}$ percent & percent $\mathrm{Al}^{(\mathrm{V})}$ & $\mathrm{Al}^{(\mathrm{VI})}$ percent \\
\hline $0.5 \mathrm{mM} \mathrm{Al-Si}$ & 10 & -85.7 & 18 & 5 & 77 \\
\hline $0.5 \mathrm{mM}$ Al-Si-DOC & 10 & -87.9 & 16 & 5 & 79 \\
\hline $0.75 \mathrm{mM} \mathrm{Al-Si}$ & 20 & -83.1 & 24 & 5 & 71 \\
\hline $0.75 \mathrm{mM}$ Al-Si-DOC & 23 & -84.0 & 16 & 5 & 79 \\
\hline $1.0 \mathrm{mM} \mathrm{Al-Si}$ & 18 & -84.6 & 26 & 5 & 69 \\
\hline $1.0 \mathrm{mM} \mathrm{Al-Si-DOC}$ & 21 & -85.8 & 22 & 5 & 73 \\
\hline
\end{tabular}

bands to lineshapes calculated from a random distribution of electric field gradients [41]. These simulations reproduce well the characteristic peak shapes, particularly the broad tail extending to lower chemical shifts most evident in the peak for $\mathrm{Al}^{\mathrm{VI}}$. The best-fit lineshape parameters (Table 4) varied only slightly among the samples: $\delta_{\text {iso }} \approx 7.9 \pm 0.3 \mathrm{ppm}$ and mean quadrupolar coupling constant, $\mathrm{Cq}=2.8 \mathrm{MHz}$ for $\mathrm{Al}^{\mathrm{VI}} ; \delta_{\text {iso }} \approx 63 \pm 1 \mathrm{ppm}$ and $C q=4.2 \mathrm{MHz}$ for $\mathrm{Al}^{\mathrm{IV}} ; \delta_{\text {iso }} \approx$ $36 \pm 1 \mathrm{ppm}$ for $\mathrm{Al}^{\mathrm{V}}$. An average $C q$ value of $4.2 \mathrm{MHz}$ was used to fit the $\mathrm{Al}^{\mathrm{V}}$ peak shape, which gave a constant relative intensity of 5\% for all samples. These values are in reasonable agreement with high-field $(217 \mathrm{MHz})$ spectra obtained for the $1.0 \mathrm{mM}$ Al samples (Figures $6(\mathrm{~g})$ and $6(\mathrm{~h})$ ), which give peak positions at $62.0,34.0$, and $6.0 \mathrm{ppm}$.

The $1.0 \mathrm{mM}$ Al samples (Figures 6(e) and 6(f)) contain a lower proportion of $\mathrm{Al}^{\mathrm{VI}}(69-73 \%)$ and larger proportion of $\mathrm{Al}^{\mathrm{IV}}(22-26 \%)$ relative to other samples. The $0.75 \mathrm{mM}$ samples (Figures 6(c) and 6(d)) contain $71-79 \% \mathrm{Al}^{\mathrm{VI}}$ and $16-24 \% \mathrm{Al}^{\mathrm{IV}}$ and the $0.5 \mathrm{mM}$ samples (Figures $6(\mathrm{a})$ and 6(b)) $77-79 \% \mathrm{Al}^{\mathrm{VI}}$ and $16-18 \% \mathrm{Al}^{\mathrm{IV}}$ (Table 4). Small, but systematic, increases in the $\mathrm{Al}^{\mathrm{VI}} / \mathrm{Al}^{\mathrm{IV}}$ ratios were noted for samples precipitated with HA (Figures 6(a), 6(c), 6(e), and $6(\mathrm{~g}))$ corresponding to $2-8 \%$ more $\mathrm{Al}^{\mathrm{VI}}$ compared to the samples precipitated from binary Al-Si solutions. In each case, the decrease in $\mathrm{Al}^{\mathrm{IV}}$ fraction correlates with a more negative chemical shift for the broad ${ }^{29} \mathrm{Si}$ component, consistent with a decrease in the average number of $\mathrm{Al}^{\mathrm{IV}}$ bonded to polymerized Si. Other than these minor changes in relative intensity, virtually no difference in the ${ }^{27} \mathrm{Al}$ spectra of samples coprecipitated with DOC was observed compared to those from HA-free solutions.

Results from ${ }^{29} \mathrm{Si} \mathrm{MAS/NMR}$ indicate the presence of both short-range ordered imogolite-like structures plus more polymerized Si environments, which is typical of allophane. The highest fraction of imogolite-like $\mathrm{Si}$ is observed in the $0.75 \mathrm{mM}$ solids, consistent with inferences from FTIR analysis. Results from ${ }^{27} \mathrm{Al} \mathrm{MAS} / \mathrm{NMR}$ also indicate the presence of $\mathrm{Al}^{\mathrm{IV}}$ in all samples. Tetrahedral $\mathrm{Al}$ is typically not observed in natural and synthetic imogolite phases $[29,39]$, and its occurrence along with that of polymerized Si suggests the presence of allophane or aluminosilicate gel [36]. For natural allophanes with $\mathrm{Al} / \mathrm{Si} 2.3-2.70$, the

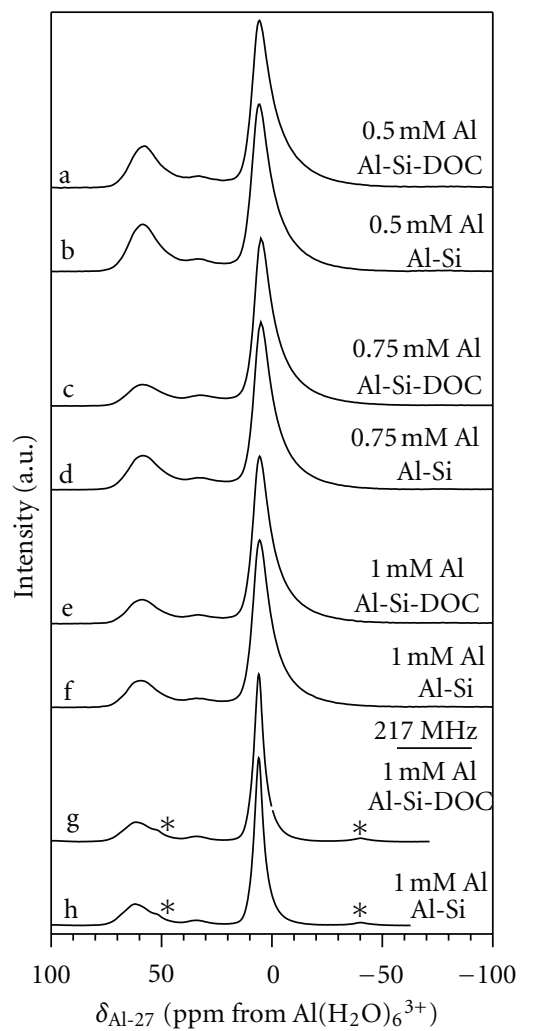

FIGURE 6: ${ }^{27} \mathrm{Al}$ MAS/NMR spectra of precipitates from solutions with $0.5 \mathrm{mM} \mathrm{Si}$ and (a-b) $0.5 \mathrm{mM} \mathrm{Al}$; (c-d) $0.75 \mathrm{mM} \mathrm{Al}$; (e-h) $1.0 \mathrm{mM} \mathrm{Al}$; with and without $6 \mathrm{mg} / \mathrm{L}$ DOC as indicated. All spectra taken with SP excitation at $130.3 \mathrm{MHz}(11.7 \mathrm{~T})$ and $18 \mathrm{kHz}$ spinning rate, except (g-h) obtained at $217 \mathrm{MHz}(19.5 \mathrm{~T})$, spinning at $10 \mathrm{kHz}$. Asterisks denote spinning sidebands.

ratio of $\mathrm{Al}^{\mathrm{IV}} / \mathrm{Al}^{\text {total }}$ is typically $0.015-0.04\left(1.5-4 \% \mathrm{Al}^{\mathrm{IV}}\right)$ as determined by ${ }^{27} \mathrm{Al} \mathrm{MAS/NMR} \mathrm{[29].} \mathrm{Assuming} \mathrm{that}$ $\mathrm{Al}^{\mathrm{IV}} / \mathrm{Al}^{\text {total }}$ ratios are close to those of natural samples or synthetic imogolite-like allophane, $\mathrm{Al}^{\mathrm{IV}}$ concentrations in our samples are higher than expected if allophane was the only constituent. This result suggests that some fraction of $\mathrm{Al}^{\mathrm{IV}}$ could be associated with polymerized $\mathrm{Si}$ in a separate amorphous hydrated aluminosilicate gel in these samples. 
Although the presence of an amorphous Al-(oxy)hydroxide cannot be ruled out, such materials generally contain lower $\mathrm{Al}^{\mathrm{IV}} / \mathrm{Al}^{\mathrm{VI}}$ ratios than observed here. It should be noted that the role of $\mathrm{Al}^{\mathrm{IV}}$ and polymerized $\mathrm{Si}$ in allophane remains uncertain, with some evidence that these signals arise from an impurity in natural allophane [42]. The $\mathrm{Al}^{\mathrm{V}}$ that is observed for all samples could represent an intermediate product in the transition between allophane and imogolite which involves transformation of $\mathrm{Al}^{\mathrm{IV}}$ to $\mathrm{Al}^{\mathrm{VI}}$ [39]. The presence of $\mathrm{Al}^{\mathrm{V}}$ and the apparent coexistence of several phases demonstrate the transitional nature of these samples. The NMR data provide evidence for a mixture of imogolite-like structures, allophone, and aluminosilicate gel in all samples, with the fractions of both imogolitelike environments and $\mathrm{Al}^{\mathrm{IV}}$ increasing with increasing initial $\mathrm{Al}$ concentration. For solids generated in the presence of $\mathrm{HA}$, consistently lower $\mathrm{Al}^{\mathrm{IV}} / \mathrm{Al}^{\mathrm{VI}}$ ratios combined with more imogolite-like Si suggest less aluminosilicate gel formed in these systems.

\section{Discussion}

4.1. Al-Si Systems. In the experimental solutions, Si should have been dominantly monomeric $(\mathrm{pH}<9$; $[\mathrm{Si}]<2-3 \mathrm{mM})$ [43], a form thought to have a low affinity for $\mathrm{Al}$, and as a consequence Al-(oxy)hydroxide phases are expected to polymerize relatively rapidly [44]. However, the precipitates have low $\mathrm{Al} / \mathrm{Si}$ ratios implying limited polymerization of separate Al-(oxy)hydroxide phases and instead enhanced formation of allophane and aluminosilicate gel.

The formation of poorly crystalline aluminosilicates in Al-Si solutions agrees with previous observations. For example, the $\mathrm{Al} / \mathrm{Si}$ ratios of the initial solutions and precipitated solids for the $0.5 \mathrm{mM}$ and $1.0 \mathrm{mM} \mathrm{Al-Si}$ samples are similar to those observed for $\mathrm{pH} 4.0-4.5$ solutions aged for 7 years at $25^{\circ} \mathrm{C}$ [45]. Despite higher $\mathrm{pH}$ and shorter aging times, the current precipitates are compositionally similar to and thus may be the precursors of these precipitates [45]. The consistently higher fractions of imogolite-like Si observed in 0.75 and $1.0 \mathrm{mM} \mathrm{Al-Si-DOC}$ solids show that over short reaction times dissolved organic matter promotes the formation of imogolite-like material.

4.2. Al-Si-HA Systems. At $\mathrm{pH} 6 \mathrm{HA}$ is soluble, deprotonated, and thus able to complex with $\mathrm{Al}$, which otherwise polymerizes rapidly [12]. Organics are known to inhibit $\mathrm{Al}$ polymerization, depending upon the affinity of the ligand for $\mathrm{Al}$ [46-48]. Because $\mathrm{HA}$ has a strong affinity for $\mathrm{Al}$, polymerization is reduced, and the formation of amorphous Al phases is promoted $[49,50]$, as indicated by the thermodynamic modeling of the initial compositions of the experimental solutions. As Si alone also reduces $\mathrm{Al}$ polymerization, and the number of Al-HA binding sites is limited, $\mathrm{Al}$-(oxy) hydroxide polymerization is further reduced in the presence of both Si and HA.

Precipitates in HA-bearing systems contain a significant portion of organic matter, suggesting insoluble metal-organo complexes. In pH 5-6, Si-free, Al-HA solutions, this can be attributed to chelation, sorption of humics on $\mathrm{Al}(\mathrm{OH})_{3}$ flocs, and/or coprecipitation mechanisms [51]. The addition of $\mathrm{Si}$ and subsequent detection in the precipitate suggests that these mechanisms involve aluminosilicate material. Results from experiments with only Si and HA show no independent interaction of these two components. This is because $\mathrm{Si}$ prefers to be tetrahedrally coordinated and so forms weak complexes with HA carboxylic functional group oxygens, compared to the stable five-membered chelate rings that readily form with $\mathrm{Al}$ [52]. Because Si-HA complexation is negligible, any interaction of Si with HA is likely to proceed indirectly. Thus, the precipitation mechanisms for Si may involve insoluble Al-bridged Si-Al-HA complexes.

At low initial HA concentrations $\left(\sim 12 \mathrm{mg} \mathrm{L}^{-1} \mathrm{HA}\right)$ and at $25^{\circ} \mathrm{C}$ for short reaction times $(20 \mathrm{~h})$, pure imogolite did not dominate the precipitate at any of the solution $\mathrm{Al} / \mathrm{Si}$ ratios. However, concentrations of $\mathrm{HA}>300 \mathrm{mg} \mathrm{L}^{-1}$ appeared to inhibit imogolite formation from solutions with $\mathrm{Al} / \mathrm{Si}$ ratios of 2 , heated to $96-100^{\circ} \mathrm{C}$ and aged for up to 110 hours [14]. Below this threshold pure imogolite was observed as the only detectable precipitate phase. The lower temperatures and shorter aging times in the current work are not conducive to the formation of pure imogolite, and therefore the role of HA is notably different from that reported previously. Results also suggest that any inhibitory effect of HA is shifted to lower concentrations relative to the published experimental results at higher temperature and much longer reaction time. For example, for $0.5 \mathrm{mM}$ initial $\mathrm{Al}$ samples the presence of HA reduced the quantity of precipitate to a small extent. Though concentrations $>12 \mathrm{mg} \mathrm{L}^{-1} \mathrm{HA}$ were not used to generate solids for further analysis, observations from experiments with $\sim 18 \mathrm{mg} \mathrm{L}^{-1}$ $\mathrm{HA}(9 \mathrm{mg} / \mathrm{L}$ DOC) suggest that more $\mathrm{Al}$ preferentially binds to the organics resulting in less Al-Si complexation and a reduction in aluminosilicate solid formation under these conditions. This may be interpreted as a slight inhibitory effect of HA on aluminosilicate formation at higher HA concentrations. On the other hand, the effect of HA on some solids characterized in this study was to produce a small but detectable increase in the production of imogolite-like material relative to aluminosilicate gel in comparison to HAfree systems.

4.3. Relation to Natural Soil Systems. The studied conditions apply to those that may be observed in natural systems for allophane- and imogolite-bearing horizons of some andisols and spodosols. These soils are typically characterized by low DOC concentrations, $\mathrm{pH}$ on the order of 5-6.5, and sufficient Si to promote imogolite formation [5]. Current results show that although allophane can be produced in organic-free solutions, organic matter seems to promote the formation of imogolite-like structures when present in low concentrations. These structures in turn may be precursors to a pure imogolite phase. Organic matter may thus play an active role in the formation of both allophane and potentially imogolite in soils, which becomes evident in natural soils with high organic content. In some volcanic andisols, allophane production can be limited by enhanced Al-humic complexation, as observed for $0.5 \mathrm{mM} \mathrm{Al}$ solids, 
termed an antiallophanic process [53]. However, this apparent inhibitory effect does not apply to all soils as high organic $\mathrm{C}$ coinciding with high allophane content has been observed for some Argentinean andisols [54] and tropical volcanic soils [6]. In the latter case, allophane and imogolite have a high capacity to store organic matter thus stabilizing and slowing $\mathrm{C}$ cycling in soils. In the current study, this is alluded to by the high $\mathrm{C}$ content of the $0.75 \mathrm{mM}$ initial Al-Si-DOC solid, combined with the highest fraction of imogolite-like material relative to solids from other experiments. Results also indicate the importance of $\mathrm{Al} / \mathrm{Si}$ and $\mathrm{Al} / \mathrm{C}$ ratios in this process. In addition, Basile-Doelsch et al. [6] observed that organic matter formed chelates with allophane, inhibiting the formation of more crystalline phases such as feldspars and gibbsite. The stabilizing effects of organics on aluminosilicate phases may in turn explain the subtle, but systematic preference for more imogolitelike material in HA-bearing samples in the current study. Here, Al-HA binding might increase the production of amorphous aluminosilicate minerals by slowing not only Alpolymerization, but aluminosilicate polymerization which would otherwise increase the fraction of gel-like material, as observed in HA-free solutions. Hence, organic matter may stabilize and promote the formation of imogolitelike material, which can in turn facilitate the sequestration and storage of organic matter. This has implications for global warming and associated climate change, whereby enhanced soil weathering and productivity with increasing temperature can accelerate the production of allophanic soils which in turn can increasingly sequester organic carbon. In natural systems, the observed disparities in the role of organic material in allophane and imogolite synthesis may be attributed to factors such as parent material and climate, which are critical during soil formation processes [6]. In turn, these factors can dictate $\mathrm{Al} / \mathrm{Si}$ and $\mathrm{Al} / \mathrm{C}$ ratios in soil systems, which are based on results of the current study, determining the role of organic material in allophane and imogolite neogenesis.

\section{Conclusions}

Solids with $\mathrm{Al} / \mathrm{Si}$ ratios ranging from 2.2-2.7 were formed from solutions with $0.5,0.75$, and $1.0 \mathrm{mM}$ initial $\mathrm{Al}$, and aqueous $\mathrm{Al} / \mathrm{Si}$ and $\mathrm{Al} / \mathrm{C}$ ratios of $1,1.5$, and 2. Allophane was the dominant mineral in all solids, with the fraction of imogolite-like Si and aluminosilicate gel depending on initial solution composition. At $0.5 \mathrm{mM}$ initial $\mathrm{Al}$, the presence of HA did not significantly affect the composition of the precipitate or the fraction of imogolite-like material. At higher initial $\mathrm{Al}$, formation of imogolite-like structures was enhanced, with slightly higher fractions observed in DOCbearing solids, and the highest fraction for a solid formed from a solution of $0.75 \mathrm{mM} \mathrm{Al}, 0.5 \mathrm{mM} \mathrm{Si}$, and $6 \mathrm{mg} / \mathrm{L} \mathrm{DOC}$. The amount of aluminosilicate gel increased with increasing initial $\mathrm{Al}$ concentration, but was reduced in the presence of HA.
Results of this study demonstrate the influence of HA on the formation of aluminosilicates under conditions applicable to certain soil systems. Allophane and imogolite-like material were successfully synthesized at ambient conditions in short reaction times, both in the presence and absence of $\mathrm{HA}$ at environmentally relevant concentrations of $\mathrm{Al}$, $\mathrm{Si}$, and DOC. Both $\mathrm{Si}$ and HA limit, if not prevent, the polymerization of $\mathrm{Al}$-(oxy)hydroxide phases. HA further limits the polymerization of aluminosilicate gel and has a subtle, but consistent effect on increasing the fraction of imogolite-like material relative to HA-free systems. The influence of $\mathrm{HA}$ on the formation of poorly crystalline aluminosilicates, contingent upon initial $\mathrm{Al} / \mathrm{Si}$ and $\mathrm{Al} / \mathrm{C}$ ratios, along with a stabilizing effect of the mineral on the organic phase via chelation or coprecipitation, may explain the coincidence of allophanic soil horizons with organics in some soil systems. This in turn has implications for C storage and sequestration.

\section{Acknowledgments}

Dr. Zhehong Gan, National High Magnetic Field Laboratory is thanked for collecting the high-field ${ }^{27} \mathrm{Al}$ NMR spectra. Funding is gratefully acknowledged from the National Science Foundation through the Grant EAR-0455938 from the University of Illinois at Chicago.

\section{References}

[1] G.F. Vance, F. J. Stevenson, and F. J. Sikora, "Environmental chemistry of aluminum-organic complexes," in The Environmental Chemistry of Aluminum, G. Sposito, Ed., pp. 169-220, Lewis, Boca Raton, Fla, USA, 1995.

[2] H. Bilinski, L. Horvath, N. Ingri, and S. Sjoberg, "Aluminosilicate phases during initial clay formation: $\mathrm{H}^{+}-\mathrm{Al}^{3+}$-oxalic acidSilicic acid- $\mathrm{Na}^{+}$system," Journal of Soil Science, vol. 41, no. 1, pp. 119-132, 1990.

[3] K. Wada, "Structure and formation of non- and paracrystalline aluminosilicate clay minerals: a review," in Clay Controlling the Environment, G. J. Churchman, R. W. Fitzpatrick, and R. A. Eggleton, Eds., pp. 443-448, CSIRO Publishing, Melbourne, Australia, 1995.

[4] R. L. Parfitt, "Allophane and imogolite: role in soil biogeochemical processes," Clay Minerals, vol. 44, no. 1, pp. 135-155, 2009.

[5] F. C. Ugolini and R. A. Dahlgren, "Weathering environments and occurrence of imogolite/allophane in selected Andisols and Spodosols," Soil Science Society of America Journal, vol. 55, no. 4, pp. 1166-1171, 1991.

[6] I. Basile-Doelsch, R. Amundson, W. E. E. Stone et al., "Mineralogical control of organic carbon dynamics in a volcanic ash soil on La Réunion," European Journal of Soil Science, vol. 56, no. 6, pp. 689-703, 2005.

[7] Y. Arai, D. L. Sparks, and J. A. Davis, "Arsenate adsorption mechanisms at the allophane-Water interface," Environmental Science and Technology, vol. 39, no. 8, pp. 2537-2544, 2005.

[8] L. Denaix, I. Lamy, and J. Y. Bottero, "Structure and affinity towards $\mathrm{Cd}^{2+}, \mathrm{Cu}^{2+}, \mathrm{Pb}^{2+}$ of synthetic colloidal amorphous aluminosilicates and their precursors," Colloids and Surfaces A, vol. 158 , no. 3, pp. 315-325, 1999. 
[9] C. J. Lind and J. D. Hem, Effects of Organic Solutes on Chemical Reactions of Aluminum, Geological Survey Water-Supply Paper 1827-G, United States Government Printing Office, Wash, USA, 1975.

[10] G. G. Lindner, H. Nakazawa, and S. Hayashi, "Hollow nanospheres, allophanes "all-organic" synthesis and characterization," Microporous and Mesoporous Materials, vol. 21, no. 4-6, pp. 381-386, 1998.

[11] G. H. Koenderink, S. G. J. M. Kluijtmans, and A. P. Philipse, "On the synthesis of colloidal imogolite fibers," Journal of Colloid and Interface Science, vol. 216, no. 2, pp. 429-431, 1999.

[12] J. D. Hem and C. J. Lind, "Kaolinite synthesis at $25^{\circ} \mathrm{C}$," Science, vol. 184, no. 4142, pp. 1171-1173, 1974.

[13] K. Inoue and P. M. Huang, "Influence of citric acid on the natural formation of imogolite," Nature, vol. 308, no. 5954, pp. 58-60, 1984.

[14] K. Inoue and P. M. Huang, "Perturbation of imogolite formation by humic substances," Soil Science Society of America Journal, vol. 54, no. 5, pp. 1490-1497, 1990.

[15] J. P. Gustafsson, Visual MINTEQ (VMINTEQ) Version 2.53, KTH, Department of Land and Water Resources Engineering, Stockholm, Sweden, 2007.

[16] J. P. Gustafsson, "Modeling the acid-base properties and metal complexation of humic substances with the Stockholm Humic Model," Journal of Colloid and Interface Science, vol. 244, no. 1, pp. 102-112, 2001.

[17] J. D. Ritchie and E. Michael Perdue, "Proton-binding study of standard and reference fulvic acids, humic acids, and natural organic matter," Geochimica et Cosmochimica Acta, vol. 67, no. 1, pp. 85-93, 2003.

[18] F. Gérard, J. P. Boudot, and J. Ranger, "Consideration on the occurrence of the $\mathrm{Al}_{13}$ polycation in natural soil solutions and surface waters," Applied Geochemistry, vol. 16, no. 5, pp. 513529, 2001.

[19] S. Hiradate and N. U. Yamaguchi, "Chemical species of $\mathrm{Al}$ reacting with soil humic acids," Journal of Inorganic Biochemistry, vol. 97, no. 1, pp. 26-31, 2003.

[20] D. K. Nordstrom and H. M. May, “Aqueous equilibrium data for mononuclear aluminum species," in The Environmental Chemistry of Aluminum, G. Sposito, Ed., pp. 29-55, CRC Press, Boca Raton, Fla, USA, 1989.

[21] G. S. Pokrovski, J. Schott, J. C. Harrichoury, and A. S. Sergeyev, "The stability of aluminum silicate complexes in acidic solutions from 25 to $150^{\circ} \mathrm{C}$," Geochimica et Cosmochimica Acta, vol. 60, no. 14, pp. 2495-2501, 1996.

[22] R. M. Smith and A. E. Martell, in NIST Critically Selected Stability Constants of Metal Complexes Database, NIST, Gaithersburg, Md, USA, 7th edition, 2003.

[23] K. A. Thorn, D. W. Folan, and P. MacCarthy, "Characterization of the international humic substances society standard and reference fulvic and humic acids by solution state carbon$13\left({ }^{13} \mathrm{C}\right)$ and hydrogen-1 $\left({ }^{1} \mathrm{H}\right)$ nuclear magnetic resonance spectrometry," in U.S. Geological Survey, Water-Resources Investigations Report 89-4196, p. 93, 1989.

[24] J. P. Pinheiro, A. M. Mota, and M. F. Benedetti, "Effect of aluminum competition on lead and cadmium binding to humic acids at variable ionic strength," Environmental Science and Technology, vol. 34, no. 24, pp. 5137-5143, 2000.

[25] J. Ganor, T. J. Huston, and L. M. Walter, "Quartz precipitation kinetics at $180^{\circ} \mathrm{C}$ in $\mathrm{NaCl}$ solutions-Implications for the usability of the principle of detailed balancing," Geochimica et
Cosmochimica Acta, vol. 69, no. 8, pp. 2043-2056, 2005.

[26] R. Gout and G. Verdes, "Effect of crystallinity on diaspore and boehmite relative stability," European Journal of Mineralogy, vol. 5, no. 2, pp. 215-217, 1993.

[27] F. Ohashi, S. I. Wada, M. Suzuki, M. Maeda, and S. Tomura, "Synthetic allophane from high-concentration solutions: nanoengineering of the porous solid," Clay Minerals, vol. 37, no. 3, pp. 451-456, 2002.

[28] R. L. Parfitt and J. M. Kimble, "Conditions for formation of allophane in soils," Soil Science Society of America Journal, vol. 53, no. 3, pp. 971-977, 1989.

[29] P. Ildefonse, R. J. Kirkpatrick, B. Montez, G. Calas, A. M. Flank, and P. Lagarde, "27 Al MAS NMR and aluminum Xray absorption near edge structure study of imogolite and allophanes," Clays \& Clay Minerals, vol. 42, no. 3, pp. 276-287, 1994.

[30] F. Ohashi, S. Tomura, K. Akaku, S. Hayashi, and S. I. Wada, "Characterization of synthetic imogolite nanotubes as gas storage," Journal of Materials Science, vol. 39, no. 5, pp. 17991801, 2004.

[31] D. G. Lumsdon and V. C. Farmer, "Solubility characteristics of proto-imogolite sols: how silicic acid can de-toxify aluminium solutions," European Journal of Soil Science, vol. 46, no. 2, pp. 179-186, 1995.

[32] J. P. Gustafsson, E. Karltun, and P. Bhattacharya, "Allophane and imogolite in Swedish soils," Research Report TRITA-AMI 3046, Royal Institute of Technology, Stockholm, Sweden, 1998.

[33] H. He, T. L. Barr, and J. Klinowski, "ESCA and solid-state NMR studies of allophane," Clay Minerals, vol. 30, no. 3, pp. 201-209, 1995.

[34] M. Tani, C. Liu, and P. M. Huang, "Atomic force microscopy of synthetic imogolite," Geoderma, vol. 118, no. 3-4, pp. 209-220, 2004.

[35] P. F. Barron, M. A. Wilson, A. S. Campbell, and R. L. Frost, "Detection of imogolite in soils using solid state ${ }^{29}$ Si NMR," Nature, vol. 299, no. 5884, pp. 616-618, 1982.

[36] B. A. Goodman, J. D. Russell, B. Montez, E. Oldfield, and R. J. Kirkpatrick, "Structural studies of imogolite and allophanes by aluminum-27 and silicon-29 nuclear magnetic resonance spectroscopy," Physics and Chemistry of Minerals, vol. 12, no. 6, pp. 342-346, 1985.

[37] S. Hiradate, "Structural changes of allophane during purification procedures as determined by solid-state ${ }^{27} \mathrm{Al}$ and ${ }^{29} \mathrm{Si}$ NMR," Clays and Clay Minerals, vol. 53, no. 6, pp. 653-658, 2005.

[38] F. J. Doucet, C. Schneider, S. J. Bones et al., "The formation of hydroxyaluminosilicates of geochemical and biological significance," Geochimica et Cosmochimica Acta, vol. 65, no. 15, pp. 2461-2467, 2001.

[39] S. Strekopytov and C. Exley, "Thermal analyses of aluminium hydroxide and hydroxyaluminosilicates," Polyhedron, vol. 25, no. 8, pp. 1707-1713, 2006.

[40] C. W. Childs, S. Hayashi, and R. H. Newman, "Five-coordinate aluminum in allophane," Clays and Clay Minerals, vol. 47, no. 1, pp. 64-69, 1999.

[41] D. Coster, A. L. Blumenfeld, and J. J. Fripiat, "Lewis acid sites and surface aluminum in aluminas and zeolites: a highresolution NMR study," Journal of Physical Chemistry, vol. 98, no. 24, pp. 6201-6211, 1994.

[42] S. Hiradate and S. I. Wada, "Weathering process of volcanic glass to allophane determined by ${ }^{27} \mathrm{Al}$ and ${ }^{29} \mathrm{Si}$ solid-state 
NMR," Clays and Clay Minerals, vol. 53, no. 4, pp. 401-408, 2005.

[43] R. K. Iler, The Chemistry of Silica: Solubility, Polymerization, Colloid and Surface Properties, and Biochemistry, John Wiley \& Sons, 1979.

[44] P. D. Taylor, R. Jugdaohsingh, and J. J. Powell, "Soluble silica with high affinity for aluminium under physiological and natural conditions," Journal of the American Chemical Society, vol. 119, no. 38, pp. 8852-8856, 1997.

[45] S. I. Wada, "Imogolite synthesis at $25^{\circ} \mathrm{C}$," Clays \& Clay Minerals, vol. 35, no. 5, pp. 379-384, 1987.

[46] F. Thomas, A. Masion, J. Y. Bottero, J. Rouiller, F. Montigny, and F. Genevrier, "Aluminum(III) speciation with hydroxy carboxylic acids. ${ }^{27} \mathrm{Al}$ NMR study," Environmental Science and Technology, vol. 27, no. 12, pp. 2511-2516, 1993.

[47] A. Masion, F. Thomas, J. Y. Bottero, D. Tchoubar, and P. Tekely, "Formation of amorphous precipitates from aluminumorganic ligands solutions: macroscopic and molecular study," Journal of Non-Crystalline Solids, vol. 171, no. 2, pp. 191-200, 1994.

[48] A. Violante and P. Violante, "Influence of $\mathrm{pH}$, concentration, and chelating power of organic-anions on the synthesis of aluminum hydroxides and oxyhydroxides," Clays Clay Miner, vol. 28, pp. 425-434, 1980.

[49] M. R. Jekel, "Interactions of humic acids and aluminium salts in the flocculation process," Water Research, vol. 20, no. 12, pp. 1535-1542, 1986.

[50] X. Lu, Z. Chen, and X. Yang, "Spectroscopic study of aluminium speciation in removing humic substances by $\mathrm{Al}$ coagulation," Water Research, vol. 33, no. 15, pp. 3271-3280, 1999.

[51] M. Petrović and M. Kaštelan-Macan, "Interaction of humic substances and aluminum formation of insoluble associates," Food Technology and Biotechnology, vol. 34, no. 2-3, pp. 81-85, 1996.

[52] G. S. Pokrovski and J. Schott, "Experimental study of the complexation of silicon and germanium with aqueous organic species: implications for germanium and silicon transport and $\mathrm{Ge} / \mathrm{Si}$ ratio in natural waters," Geochimica et Cosmochimica Acta, vol. 62, no. 21-22, pp. 3413-3428, 1998.

[53] S. Shoji, M. Nanzyo, and R. Dahlgren, "Volcanic ash soils. genesis. Properties and utilization," in Developments in Soil Science, vol. 21, p. 288, Elsevier Press, Amsterdam, Netherlands, 1993.

[54] P. Broquen, J. C. Lobartini, F. Candan, and G. Falbo, "Allophane, aluminum, and organic matter accumulation across a bioclimatic sequence of volcanic ash soils of Argentina," Geoderma, vol. 129, no. 3-4, pp. 167-177, 2005. 

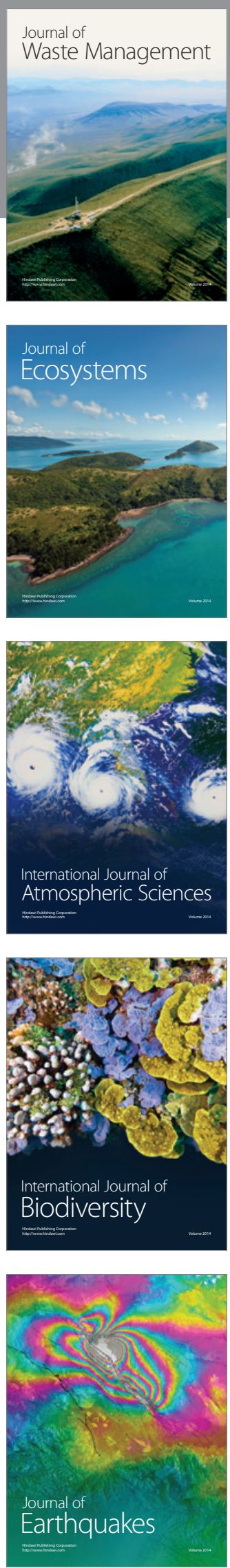
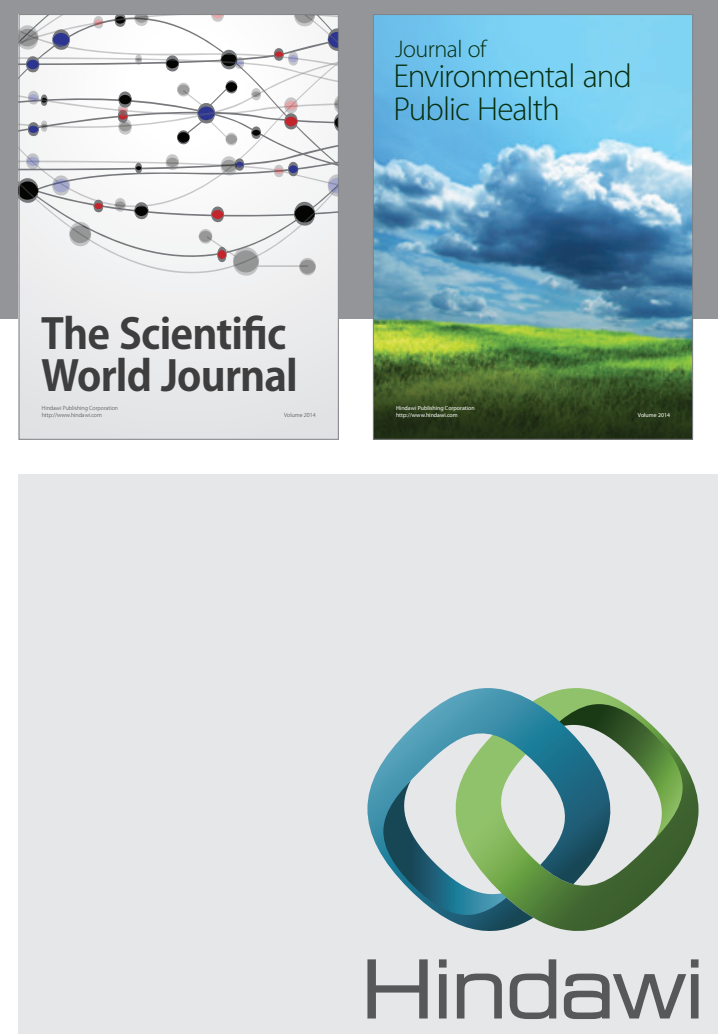

Submit your manuscripts at

http://www.hindawi.com
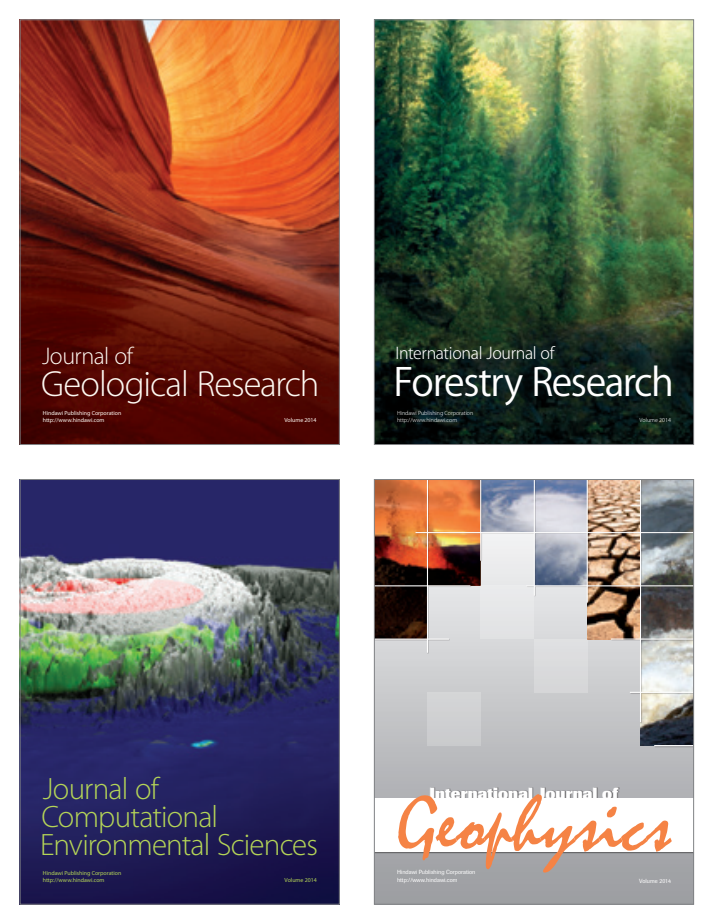
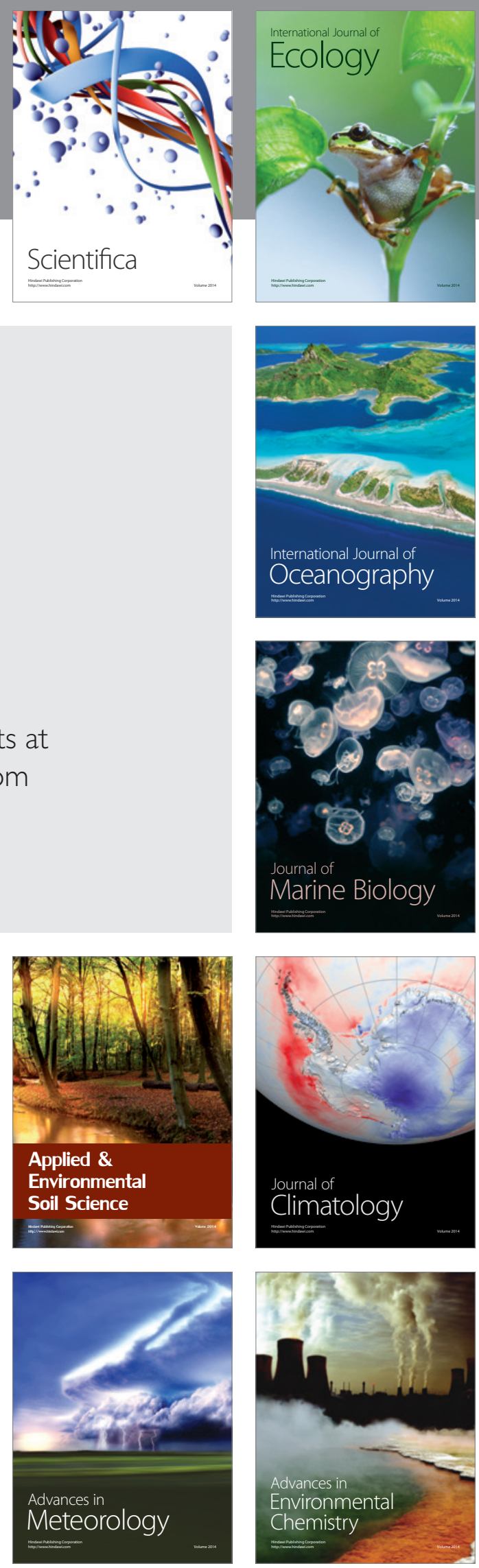